\title{
Timing Theatrical Action in the English Medieval Theatre
}

Perhaps one of the reasons why little has been written about timing theatrical action in the English medieval theatre is because there is very little evidence of it. Narratives in extant play texts create their own imaginative realities and as such are unreliable as indicators of timing requirements in the execution of action. Such texts often refer to 'time' but not 'timing'. 'Time' in the abstract or as theme occurs in many plays. However, 'timing' - that which deals with impulse, rate, frequency and duration by which action occurs - is not determined with any precision through the narratives of play texts.

Because the text is unreliable in conditioning timing, resort needs to be made to information that is not primarily driven by imaginative or narrative requirements. Outside the occasional eye-witness account of timing, the principal means of identifying timing in action may be seen in the stage direction. For the same reason that the text is considered to be unreliable so should the 'implicit' stage direction also be regarded as unreliable. The 'implicit' stage direction is often regarded as that narrative requirement of action contained in the text. The 'explicit' stage direction, however, of which there are many, generally exists outside the narrative and addresses the people who put on the play; this is done in pragmatic terms as a means of acheiving required action.

Thus, this paper will address issues of timing as they are determined by explicit stage directions; it will not address the more generalized, thematic, or narrative use of time as content or metaphor. The stance toward timing will be that required on behalf of the performer. Instances of timed activity, as recorded by explicit stage directions, invariably suggest existence of implicit theatrical rules or conventions by which the passage of time and the need for timed action and its preparation is required. ${ }^{1}$ Explicit stage directions that indicate the need for timed response occur through stipulation of 'instantaneousness', 'simultaneity', 'readiness', and requirements 'to wait'. 
However, before examining these notions and their relevance to timing it is necessary to consider a number of apparently clear instructions contained in some explicit stage directions where the content does not exist outside the narrative, and it might be useful to identify them and their kind in order to relegate them as indicators of timing. For instance, in the Resurrexio Domini of the Cornish Ordinalia a stage direction reads: 'et lauabit manus et statim morietur' [And he shall wash his hands, and shall die immediately]. ${ }^{2}$ The death refers to that of the Traveller and is not immediate in the literal sense for a death speech of some further eight lines then takes place. Other apparent, yet misleading, timing requirements for the instantaneous expressed in both Latin and English stage directions occur through opening demands of 'Here...(something shall happen)' and 'Then ... (something shall happen).' Although these kinds of statements are numerous and will be well known, perhaps some typical examples should be cited. In The Play of the Sacrament a stage direction states: 'Here pe Ost must blede.' ${ }^{3}$ In the Chester Play of the Nativity the requirement is: 'Tunc stella apparebit' [Then the star shall appear]. ${ }^{4}$ Stage directions that begin with the imperative 'Now ... (something shall happen)' can be as imprecise as those that require that something should happen 'Here' and 'Then', although some of these directions do occasionally require a rapid response. In The Play of the Sacrament a stage direction determines: 'Now shall pe merchantys man withdrawe hym and pe Jewe Jonathas shall make hys bost.' The same point, concerning the imprecision of timing, may be made in respect of those stage directions that require something to happen 'after', 'afterwards', or 'in the end'. In the Gwreans An Bys: The Creation of the World a stage direction determines: 'Let them fight $w^{\text {th }}$ swordis and in the end Lucyfer voydeth \& goeth downe to hell apareled fowle $w^{\text {th }}$ fyre about hem turning to hell and every degre of devylls of lether \& spirytis on cordis runing into $y^{e}$ playne and so remayne ther, 9 angells after Lucyfer goeth to hell.'6 A stage direction in the Chester Play of Noah determines: 'Then Noe with all his familye shall make a signe as though the wrought upon the shippe with divers instruements. And after that God shall speake to Noe as followeth:.' After the 'goynge owt' in which 'pe FYVE WYTTYS' sing in Wisdom, a stage direction requires: 'And aftyr pe songe entreth LUCYFER in a dewyllys aray wythowt and wythin as a prowde galonte, seynge thus on thys wyse:.'

On the face of it instructions contained in these sorts of stage directions indicate moments of timing that involve some sort of action that happens 'Here', 'Then', 'Now', and 'afterwards.' Although such directions might be said to refer to timing they are not precise in their requirements. Despite 
imperatives contained in these directions they do not stipulate exactness of timing of the sort that might be associated with the instantaneous or the start, duration, or end of timed action. Sudden responses are not demanded. However, the contained information is often important and frequently not duplicated by the text. Information coming as it does at this point in the stage direction is about the order of it. Such instructions are predominantly concerned with determining the sequence of events or position in the text, and/or its action. They do not contain instructions for timed action and may be relegated in importance.

Other references in stage directions to protagonists who 'vanish', 'appear', and 'disappear' might also be regarded as ones that indicate the need for sudden and timed action. However, these references to 'vanishing', 'appearing', and 'disappearing' are ones determined by the biblical narrative. Thus, it is not clear whether the narrative function of the stage direction may be doubled up with an additional role in the form of an instruction concerning timing to the performer. Because of this ambiguity such stage directions are also unreliable in their evidential value in respect of timed action. An example may be seen in a stage direction in Cleophas and Luke; The Appearance to Thomas in the $N$-Town Plays that appears to indicate an instantaneous reaction: 'Hic subito discedat Christus ab oculis eorum' [Here let Christ suddenly disappear from their eyes]..${ }^{9}$ Not only does action need to be created 'suddenly' but the disappearance is recorded as being 'from their eyes', that is, Cleophas and Luke and not necessarily the eyes of the audience. The same distinction is referred to in The Pilgrims in the Towneley Plays where it is recorded that Christ and the disciples: 'Tunc recumbent, et sedebit Iesus in medio eorum; tunc benedicet Iesus panem et franget in tribuspartibus, et postea euanebit ab oculis eorum; et dicet Lucas:' [Then they shall sit and Jesus shall sit between them. Then Jesus shall bless the bread and shall break it into three pieces, and afterwards vanish from their sight; and Luke shall say:].$^{10}$ In this case Cleophas and Luke express their astonishment at the suddenness of the disappearance. Whether timing of these actions and their perceived reception by characters and audience occurs at the same moment is unclear yet unlikely. The important information contained in these stage directions is that the disappearances are those perceived by the characters as demanded by the narrative. Such disappearances may not be literal in the staging reality. Other stage directions in the Chester Plays ${ }^{11}$ and The Conversion of Saint Paul ${ }^{12}$ make similar requirements but do not determine from whose perspective the disappearance occurs. In all these examples, the common function of the stage direction is to maintain the reality of and reinforce the 
biblical narrative. The staging reality that demands precise information about timing is ambiguous and unreliable.

Having set aside the kind of stage directions that do not make precise requirements of performers and/or action, it is necessary to look at examples of explicit stage directions that demand timed action through the instantaneous. In the Digby Play of Mary Magdalen, The Brome Abraham, The Last Supper: The Conspiracy with Judas and The Betrayal of Passion Play 1 of the N-Town Plays, action is intended to happen 'sodeynly' in order to achieve theatrical impact through contrast. Two such examples occur in the Digby Play of Mary Magdalen: 'Her avoydyt Syrus sodenly, and than sayyng Lazarus:' and 'Here avoydyt Jhesus sodenly, pus seyyng Mary Magdleyn:.' ${ }^{13}$ In both these cases, the 'avoiding', or withdrawing from focus, is both defined and qualified by the imperative, 'sodenly'. In The Brome Abraham, at the moment when Abraham is about to kill Isaac, a stage direction determines: 'Her Abraham drew hys stroke and pe angell toke the sword in hys hond soddenly'. ${ }^{14}$ Not only does the text determine the importance of this timed intervention, but the stage direction qualification that the action should happen 'soddenly' confirms both the narrative and staging needs. A stage direction in The Last Supper: The Conspiracy with Judas of the N-Town Plays states: 'Here Cryst enteryth into pe hous with his disciplis and ete pe paschal lomb; and in pe menetyme pe cownsel hous befornseyd xal sodeynly onclose schewyng pe buschopys, prestys and jewgys syttyng in here astat lych as it were a convocacyon; Annas seyng pus:. ${ }^{15}$ Another stage direction in the same play refers to use of the same device: 'Here the buschopys partyn in pe place, and eche of hem takyn here leve be contenawns, resortyng eche man to his place with here meny, to make redy to take Cryst. And pan xal pe place per Cryst is in sodeynly vnclose rownd abowtyn shewyng Cryst syttyng at pe table and hese dyscypulis ech in ere degré; Cryst pus seyng..' ${ }^{16}$ In The Betrayal of Passion Play 1 of the $N$-Town Plays a stage direction requires: 'Here pe aungel ascendyth $a_{3}$ en sodeynly', and later in the same play 'Here all pe Jewys falle sodeynly to pe erde whan pei here Cryst speke; and quan [he] byddyth hem rysyn, pei rysyn $a_{3} e n$, Cryst pus seyng.. ${ }^{17}$ The imperatives for sudden responses in these stage directions are essentially concerned with creating changed circumstances through visual, and possibly aural, impact. Instantaneousness is essential to the respective theatrical statements. Timing must condition the realization.

Beyond the need for timing through the immediate response is that concerned with the duration of timed moments or sequences. In addition to the examples just offered there are further stage directions in the $N$-Town Plays that refer to simultaneous action through the phrase 'and in pe menetyme.' 
One example is contained in The Conspiracy and it says: 'Here goth pe masangere forth; and in pe menetyme Cayphas shewyth himself in his skafhald arayd lych to Annas, savyng his tabbard xal be red furryd with white; ij doctorys with hym arayd with pellys aftyr pe old gyse and furryd cappys on here hedys; Cayphas pus seyng..' ${ }^{18}$ The inverse of this type of staging sequence occurs later in the same play when a stage direction establishes: 'Here comyth be masangere to Cayphas; and in pe menetyme Rewfyn and Lyon schewyn hem in pe place in ray tabardys furryd, and ray hodys abouth here neckys furryd; pe masangere seyng..' ${ }^{19}$ A simpler requirement, although equally important in maintaining the momentum of the scene, occurs through the stipulation: 'Here Annas goth down to mete with Cayphas, and in pe menetyme pus seyng..' ${ }^{20}$ In The Betrayal of Passion Play 1 of the $N$-Town Plays a further example of this sort of synchronized action is stipulated as follows: 'Here pe Jewys lede Cryst outh of pe place with gret cry and noyse, some drawyng Cryst forward, and some bakward, and so ledyng forth with here weponys alofte and lytys brennyng. And in pe menetyme, Marye Magdalene xal rennyn to oure Lady and telle here of oure Lordys takyng, pus seyng.. ${ }^{21}$

Other stage directions in the $N$-Town Plays make use of other terminology that clearly refers to the same staging requirements as that determined by the phrase 'and in pe menetyme'. In the $N$-Town play of Satan and Pilate's Wife; The Second Trial Before Pilate, a stage direction requires such dual action: 'Here enteryth Satan into pe place in pe most orryble wyse. And qwyl pat he pleyth, pei xal don on Jesus clothis and ouyrest a whyte clothe, and ledyn hym abowth pe place, and pan to Pylat be pe tyme pat hese wyf hath pleyd.'22 Use of the term 'perwhyls' in a stage direction in the $N$-Town Crucifixion that also contains the phrase 'and in pe menetyme' indicates the relative complexity of such synchronized and concurrent action: 'Here pe sympyl men xulsettyn up pese ij crossys and hangyn up pe thevys be pe armys. And perwhylys xal pe Jewys cast dyce for his clothis, and fytyn and stryvyn. And in pe menetyme xal oure Lady come with iij Maryes with here and Sen Johan with hem, settyng hem down asyde afore pe cros, oure Lady swuonyng and mornyng, and [be] leysere seyng:. ${ }^{23}$ Use of the phrases 'and in pe menetyme', 'perwhylys', and 'qwyl pat he pleyth' usually refer to the simultaneous action in at least two different locations within the staging. A consistent feature of these stage directions is that one aspect of the stipulated action is determined in order to condition the amount of time available to complete the other.

Such action derives its timing from considerations of 'simultaneity'. Here, more than one action is involved and timed to run concurrently with another. It is usual for one of these actions to dominate and the other to become subordinate to, for example, the changed focus of scenes or locations. Two 
such simultaneous or overlapping scenes do not normally carry equal focal attraction. Since they are concerned with transition or transformation one scene takes over from the other. Sometimes such simultaneity is conditioned by concurrent yet different visual and aural focus. For instance, during The Presentation of Mary in the $N$-Town Plays a stage direction informs: 'Here xal comyn alwey an aungel with dyvers presentys, goynge and comyng, and in pe tyme pei xal synge in hefne pis hympne: "Jesu Corona Virginum". And aftyr, per comyth a minister fro pe busschop with a present and seyth:. ${ }^{24}$ The timing of the angel's 'goynge and comyng' is governed by the time taken to complete 'pis hympne'. The same convention is at work in The Purification of the $N$-Town Plays where a stage direction states: 'The psalme songyn every vers, and perqwyl Symeon pleyth with pe child; and qwhan pe psalme is endyd he seyth:. ${ }^{25}$ Today, if the simultaneity within the stage direction were to be implemented it might be suggested that the 'psalme' might be used to 'cover' the action of Symeon playing with the child. However, the qualifcation in the stage direction that 'every vers' shall be 'songyn' indicates that the 'psalme' was the principal determinant of both focus and timing.

Preparation for the timed moment and its execution is illustrated through stage directions that are concerned with states of 'readiness'. In the Cornish Ordinalia, The Life of Saint Meriasek, and the $N$-Town Plays there are a number of stage directions that require properties to 'be ready' for use. In the Passio Domini of the Cornish Ordinalia during the torturing of Christ, a stage direction reads: 'hic paratur vestis ad velandum Jhc' [Here a cloth is got ready to cover Jesus]. Later, in the same play, a stage direction records: 'hic paratur flagellum per tortores et postis ad ligandum Jhm. et corda et cathena et corona spinea paratur' [Here a whip is got ready by the executioners, and a stake to bind Jesus, and a cord, and a chain, and a crown of thorns is prepared]. Later still, it is recorded: 'hic paratur spongium cum felle et aceto' [Here a sponge is made ready, with gall and vinegar]. ${ }^{26}$ Similarly, in Saint Meriasek, a representative range of stage directions records: 'her yerdis aredy for tevdar and hys men' [Here staves ready for Teudar and his men]; 'chappell aredy' [A chapel ready]; 'y' galovs aredy' [The gallows ready]; ' $y$ ' tumbe aredy' [The tomb ready] and 'a vysour aredy apon Constantyn ys face' [A mask ready upon Constantine's face]. ${ }^{27}$

In addition to the readiness of properties, there are also a number of stage directions that require named characters to 'be ready'. In The Entry into Jerusalem in the $N$-Town Plays a stage direction requires that 'pe iiij ceteseynys makyn hem redy for to mete with oure Lord ${ }^{28}$ In Saint Meriasek, a further range of stage directions include: 'her $y^{e}$ sovlys aredy' [Here the souls ready]; ' $y$ ' 
wymmen aredy $w^{t}$ ther chyldryn' [The women ready with their children]; 'armatores aredy' [Armed men ready]; and ' $y$ ' processyon aredy' [The procession ready]. ${ }^{29}$

Further to the stage directions that require properties and characters to be ready, there are some that refer to the conscious preparation of characters and performers in their readiness 'to act' or 'to play'. In the Passio Domini of the Cornish Ordinalia the following stage directions record: 'bic ancilla hostiarum sit parata ad ludendum' [Here let the portress be ready to act]; 'hic pannarius et mercenarius sint parati ad ludendum' [Here let the cloth-dealer and the workman be ready to act $].^{30}$ In the $N$-Town play of Satan and Pilate's Wife; The Second Trial Before Pilate, a stage direction requires: 'Here enteryth Satan into pe place in pe most orryble wyse. And qwyl pat he pleyth, pei xal don on Jesus clothis.' ${ }^{31}$ In addition to named characters being 'ready to act', a distinctive stage direction in Saint Meriasek requires a named actor to be ready 'to play' a named character. It reads: 'And John ergudyn aredy a horse bakke $y^{t}$ was $y^{e}$ Justis $w^{t}$ constantyn ffor to play y $y^{e}$ marchont' [And John Ergudyn, who was the Justice with Constantine, on horseback ready to play the merchant]. ${ }^{32}$

A development of this sort of information is contained in another stage direction in the Passio Domini of the Cornish Ordinalia in which it is recorded: 'bic Thomas sit presens et paratur ad ludum' [Here let Thomas be present, and ready to act]. ${ }^{33}$ In what sense is Thomas 'present'? Does this direction mean that the character is 'present' in the acting space? Does this mean that the character in his state of readiness is in view of the audience? If the character is 'present' in view of the audience, does this mean that the audience is capable of seeing the actor who plays Thomas 'acting' and 'not acting'? If this is so, how is the change from one state to the other signalled and accomplished? From the point at which the stage direction requires the character to 'be present' in his readinesss 'to act', there are some 18 lines of text to be delivered before he speaks. Other instances of characters being required 'to act' occur within a time scale determined by a variable space of some 6 to 27 lines. Clearly, stage directions that refer to 'readiness' are designed to prepare performers for an intended moment of execution when states of 'readiness' have been fulfilled; they may also refer to a distinction between conditions of 'acting' and 'not acting'. The moment of theatrical realization may therefore not only be considered to be timed but determine visual demarcation between 'not acting' and 'acting'.

Since 'readiness' is concerned with preparation of action, the time interval between the declaration of a state of 'readiness' and execution inevitably involves 'waiting'. Allusion to 'waiting' as determined by stage directions begs 
a number of questions as to the function and purpose of such activity. Is the purpose of 'waiting' concerned with the timing of an appropriate moment as determined by the narrative of the text? Or is 'waiting' identified with one or a number of staging conventions? What happens to the rest of the action of the play when a named character is required 'to wait'? What happens to the people who are required to wait?

In Saint Meriasek, several stage directions require different characters to either 'wait in the same place' or 'wait in the open'. When the women whose children are to be killed are brought in front of Constantine, he reprieves the children and a stage direction stipulates: 'tranceunt tortores et mulieres expectant in placea' [The torturers go off and the women wait in the open]. ${ }^{34}$ Constantine then addresses the women and one of them replies to his intervention. Different use of the requirement to 'wait in the open' is made of two further stage directions in Saint Meriasek. On one occasion the torturers are required 'to wait in the open' and from the same point re-enter the narrative with the First Torturers line, 'Out! let us come away, comrades!'35 Later in Saint Meriasek the Outlaws are also required 'to wait in the open space' and to re-enter the narrative with the First Outlaw's line, 'Now mates, look around!'36 Both the First Torturer's line and that of the First Outlaw seem designed to arrest attention and redirect focus of the incoming scene upon the speakers. So what have the Torturers and the Outlaws been doing in the respective intervening periods since they were required 'to wait in the open'? Have they been watching the action? Have they been ignoring the action; or seemingly ignoring the action? Have there been any signals to determine how the audience should regard such waiting 'in the open space'? Should the audience have ignored them or shut them out of its vision? Should the audience have relegated their importance and prioritized attention in favour of the speakers?

There are more stage directions in Saint Meriasek that require characters 'to wait', although the key phrase in these directions is 'to wait in the same place'. It appears, however, that different intentions may be associated with these requirements. On one occasion the Bishop of Pola 'waits in the same place'37 and in this case 'the same place' seems to refer to the place from which he last spoke. When a stage direction informs that 'Meriasek waits in the same place', 38 this also suggests that it is the place from which Meriasek last spoke. Later, when the Dean of the College is involved in the selection and promotion of Meriasek as the new Bishop of Vannes a stage direction requires of the Dean: 'ascendit et expectat ibidem' [He goes up and waits in the same place]. ${ }^{39}$ In this case the requirement refers to an elevated position occupied by the Earl of 
Vannes. A further example in the use of this requirement relates to the impending hanging of a boy whose mother seeks Mary's help and intervention. During the mother's pleading the stage direction determines: 'genuflectit et expectat ibidem' [She kneels and waits in the same place]. ${ }^{40}$ The 'same place' in this case refers to the named locus of the Church of the Blessed Mary.

Although it may not be possible to say that waiting in 'the same place' refers to a specific location, 'the same place' can refer to a number of different places both inside and outside the reality of the narrative. These 'places' can refer to staging locations, or imaginative ones within the narrative. However, all the stage directions that determine that waiting should take place appear to confirm that such action should take place at a point which is still in view of the audience.

Stage directions in other plays also refer to the act of waiting, but do so in different terms and for different purposes. Again, in The Entry into Jerusalem of the N-Town Plays, a requirement is made that 'Here Cryst rydyth out of pe place and he wyl, and Petyr and Johan abydyn stylle'. In this instance a time limit to their waiting is determined by the stage direction when it continues 'and at pe last, when pei haue don per prechyng, pei mete with Jesu'. ${ }^{41}$ In the Chester Play of Noah a similar requirement is made of Noah to 'shutt the windowe of the arke, and for a little space within the bordes hee shalbe scylent; and afterwarde openinge the windowe and lookinge rownde about sayinge. ${ }^{42} \mathrm{~A}$ further condition is made in the Chester Play of the Nativity when it is required of Joseph and Mary: 'Tunc paululum acquiescunt' [Then for a little while they are quiet]. ${ }^{43}$

Requirements to 'be still' or 'silent' for a short while are not accompanied by explanations. However, each of these instances of 'stillness' and 'silence' differs from earlier requirements 'to wait' in that they represent pivotal moments in which key narrative transformations take place. In the case of the requirement that Peter and John should 'abydn stylle' in the $N$-Town Entry into Jerusalem, the extent to which they should do this is determined by the length of time taken by Jesus to 'rydeth out of pe place' for Jesus is presumably not intended to hear the subsequent 'prechyng' about him by Peter and John. The requirement that Noah 'for a little space within the bordes ... shalbe scylent' is not only intended to convey the passage of time but also a change of location. The quietness that Joseph and Mary are required to keep in the Chester Play of the Nativity encapsulates the time taken for Christ to be born.

So why are such important narrative components completed during periods of stillness and silence? Why would an author or authors commit crucial, pivotal aspects of the narrative to be communicated through 'silence' or 'stillness' if the audience could not maintain its understanding of the narrative? 
Potential answers to these questions must refer to audience understanding of these conditions. The audience must know and recognize that time is intended to pass. Do these requirements to be 'still' and 'quiet' embody any signals or conventions that are intended to communicate that time passes? Or are these naive instructions that make for simplistic results of arbitrary communication? How does the medieval audience know that time is intended to pass?

It might be assumed that the audience did know that time passed and the literal passage of time determined by expressed needs in explicit stage directions such as 'Petyr and Johan abydyn stylle', 'Noah ... for a little space ... shalbe scylent', and Joseph and Mary 'for a little while they are quiet', stood for an imaginative passage of time in order to communicate significance of the narrative. The communicated narrative would not make sense if this understanding did not exist. Is it reasonable to suppose that communication of meaning of the narrative would be let down by inexpert handling of significant narrative elements through staging? Of course this is possible, but if such key pivotal moments are not communicated with appropriate skill through a known convention then the narrative as represented by the text is also weakened. It is interesting to note that in all the examples so far encountered of characters or actors being required 'to wait', 'be still', or 'be silent', it is always these named figures who both signal the start of the waiting period and end it. So, the dramatic and staged focus of the scene is returned to the named figure. The actor or character takes the initiative to re-focus the scene and end the period of waiting.

Another form of 'waiting' and determinant of timing occurs through what appears to be a deliberately contrived convention when characters are required to 'walk about the place' or 'walk about the stage'. In The Killing of the Children in the Digby Plays a stage direction informs: 'Here the knyghtes and Watkyn walke abought the place tylle Mary and Joseph be convied into Egipt.' Later in the same play another direction makes a similar yet developed demand: 'Here shal Symeon bere Jhesu in his armys, goyng a procession rounde aboute pe tempille, and al pis wyle pe virgynis synge "Nunc dimittis" and whan pat is don, Symeon seyth:.' 44 The same convention operates in the Passio Domini of the Cornish Ordinalia where a stage direction states: 'et tunc ipsi transeant cum jhu et parumper spaciabunt in platea dummodo nuncius eat post doctores et dicit cayphas' [And then they shall pass with Jesus, and shall walk about a little on the stage while the messenger goes after the doctors; and Caiaphas says:]. ${ }^{45} \mathrm{~A}$ stage direction referred to earlier in the N-Town play of Satan and Pilate's Wife; The Second Trial Before Pilate records: 'Here enteryth Satan into pe place in pe most orryble 
wyse. And qwyl pat he pleyth, pei xal don on Jesus clothis and ouyrest a whyte clothe, and ledyn hym abowth pe place, and pan to Pylat be pe tyme pat hese wyf hath pleyd.' 46 In each of these cases the deliberate walking around the space or stage is intended to take an amount of time that is conditioned by another simultaneous action. In The Killing of the Children the 'knyghtes and Watkyn' walk around the place for the time taken to deliver some 44 lines which is the time taken to deliver the scene between the angel, Joseph, and Mary. In the second example from The Killing of the Children Symeon processes for the time it takes to deliver the 'Nunc dimittis'. When they 'ledyn hym [Christ] abowth pe place' in the N-Town play of Satan and Pilate's Wife; The Second Trial Before Pilate the first 77 lines of the play are available to complete the action determined by the stage direction. The act of leading Christ about the place is subsumed under these 77 lines. In each of these cases the protagonists who walk around the 'place' or 'stage' can be seen to do so whilst other action takes predominant focus. The convention is that the characters walk about the space until some other dialogue, music, or action is completed. Thus the audience is being asked to accept subliminal action at the same time as they witness the main action. Such a convention is different from, yet related to, the one that requires characters to 'wait in the open' or 'wait in the same place'. Here too, the subliminal presence of the waiting characters is witnessed at the same time as the succeeding main action.

Requests through stage directions for 'stillness', 'silence', 'waiting', and 'walking about the place' in order to convey the passage of time appear at first glance to be simplistic or theatrically inept. It might be considered that such requirements demonstrate little understanding of theatrical development and appropriate techniques to communicate it. One often repeated implication is that the instigators of plays in production did not know how to communicate the passage of time to an audience, and so the most convenient way of dealing with this condition was to produce a 'silence' or a 'stillness' through which it might be hoped that the passage of time would be communicated. Although this notion is often presented as an indictment of theatrical naivety, there is no reason why such simple practices should not constitute appropriate conventions to convey meaning. The only condition of their intended value would be that the audience understood the conventions. Providing 'stillness', 'silence', 'waiting', and 'walking about the place' was permitted to stay in subliminal theatrical focus, then such simple conventions would be adequate to co-exist with the principal action. After all, such conventions are not very different from the over-exploited one frequently found in productions all over Northern Europe and the USA in the 1960s and seventies when the action was 
stilled in a 'frozen image'. The essential difference between these conventions is that the 'frozen image' invariably interrupts action whilst 'stillness', 'silence', 'waiting', and 'walking about the place' as determined by stage directions in the English medieval plays, completes or prepares for action.

The most reliable form of evidence that specifies use of timing in English medieval plays exists in the form of the explicit stage direction. Not all kinds of explicit stage directions can be used with authority to explicate timing requirements. Unreliable examples of explicit stage directions have been identified as have others that refer to 'instantaneousness', 'simultaneity', 'readiness', and requirements 'to wait'. Concern for these timing criteria has revealed additional identification of staging conventions that require 'characters' to 'wait in the same place', 'wait in the open', 'walk about the place', and 'walk about the stage' as subliminally timed action in the transformation of scenes. Such timed action is also implied by the capacity of an audience to witness states of 'acting' and 'not acting'. Both conditions were apparently conducted in the open and timed in transition.

Notes

1 For further discussion of stage directions and staging conventions, see my 'Book-Carriers: Medieval and Tudor Staging Conventions', Theatre Notebook 46 (1992), 15-30; 'Comings and Goings: English Medieval Staging Conventions', The Early Drama, Art, and Music Review 18.1 (1995), 25-34; 'Stage Directions in the Towneley Play of Jacob', The National Arts Education Archive Occasional Papers 6 (1996), 1-8; Theatre of Fire (London, 1998), xiii-xv, xxii-xxiv.

2 The Ancient Cornish Drama, Edwin Norris (ed and trans), 2 vols (Oxford, 1859, rpt 1968), 2.166-7 (1.2206).

3 The Play of the Sacrament, in Non-Cycle Plays and Fragments, Norman Davis (ed), EETS ss 1 (London, 1970), 73 (1.480).

4 The Chester Mystery Cycle, R.M. Lumiansky and David Mills (eds), 2 vols EETS ss 3 (London, 1974), 1.116 (1.508).

5 Davis, Non-Cycle Plays and Fragments, 62 (1.148).

6 Gwreans An Bys: The Creation of the World, Whitley Stokes (ed and trans) (London, 1864), 28 (1.325).

7 Lumiansky and Mills, The Chester Mystery Cycle, 1.47 (1.112).

8 Wisdom, in The Macro Plays, Mark Eccles (ed), EETS os 262 (London, 1969), 125 (1.324). Further examples are contained in Lumiansky and Mills, The 
Chester Mystery Cycle, 1.53 (1.260); The N-Town Play: Cotton MS Vespasian D.8, Stephen Spector (ed), 2 vols, EETS ss 11 (Oxford, 1991), 1.93 (1.277); 1.85 (1.146); 1.260 (1.385); The Killing of the Children, in The Late Medieval Religious Plays of Bodleian MSS. Digby 133 and E Museo 160, Donald C. Baker, John L. Murphy and Louis B. Hall, Jr (eds), EETS os 283 (Oxford, 1982), 112 (1.484).

9 Spector, The N-Town Play, 1.376 (1.216).

10 The Towneley Plays, Martin Stevens and A.C. Cawley (eds), 2 vols, EETS ss 13 (Oxford, 1994), 1.364 (1.296).

11 Lumiansky and Mills, The Chester Mystery Cycle, 1.361 (1.123); 1.366 (1.215).

12 Baker, Murphy, and Hall, The Late Medieval Religious Plays of Bodleian MSS. Digby 133 and E Museo 160, 18 (1.501).

13 Baker, Murphy, and Hall, The Late Medieval Religious Plays of Bodleian MSS. Digby 133 and E Museo 160, 33 (1.276); 61 (1.1095).

14 Davis, Non-Cycle Plays and Fragments, 52 (1.315).

15 Spector, The N-Town Play, 1.267 (1.76).

16 Spector, The N-Town Play, 1.276 (1.348).

17 Spector, The N-Town Play, 1.288 (1.64); 1.289 (1.92).

18 Spector, The N-Town Play, 1.253 (1.208).

19 Spector, The N-Town Play, 1.255 (1.244).

20 Spector, The N-Town Play, 1.256 (1.280).

21 Spector, The N-Town Play, 1.291 (1.148).

22 Spector, The N-Town Play, 1.314 (l.1).

23 Spector, The N-Town Play, 1.328 (1.92).

24 Spector, The N-Town Play, 1.93 (1.277).

25 Spector, The N-Town Play, 1.185 (l.146).

26 Norris, The Ancient Cornish Drama, 1.330-1 (1.1362); 1.384-5 (1.2048); $1.456-7$ (1.2964).

27 The Life of Saint Meriasek, Bishop and Confessor. A Cornish Drama, Whitley Stokes (ed and trans) (London, 1872), 54-5 (1.955); 64-5 (1.1152); 70-1 (1.1230); 74-5 (1.1328); 76-7 (1.1347).

28 Spector, The N-Town Play, 1.263 (1.449).

29 Stokes, The Life of Saint Meriasek, 74-5 (1.1305); 88-9 (1.1532); 88-9 (1.1546); 104-5 (1.1839).

30 Norris, The Ancient Cornish Drama, 1.320-1 (1.1224); 1.324-5 (1.1279).

31 Spector, The N-Town Play, 1.314 (1.1).

32 Stokes, The Life of Saint Meriasek, 106-7 (1.1865).

33 Norris, The Ancient Cornish Drama, 1.318-19 (1.1206).

34 Stokes, The Life of Saint Meriasek, 94-5 (1.1652). 
100 P. BUTTERWORTH

35 Stokes, The Life of Saint Meriasek, 72-3 (1.1287); 74-5 (1.1306).

36 Stokes, The Life of Saint Meriasek, 110-1 (1.1935); 120-1 (1.2086).

37 Stokes, The Life of Saint Meriasek, 84-5 (1.1474).

38 Stokes, The Life of Saint Meriasek, 118-19 (1.2085).

39 Stokes, The Life of Saint Meriasek, 164-5 (1.2853).

40 Stokes, The Life of Saint Meriasek, 208-9 (1.3590).

41 Spector, The N-Town Play, 1.260 (1.385).

42 Lumiansky and Mills, The Chester Mystery Cycle, 1.53 (1.260).

43 Lumiansky and Mills, The Chester Mystery Cycle, 1.116 (1.500).

44 Baker, Murphy and Hall, The Late Medieval Religious Plays of Bodleian MSS.

Digby 133 and E Museo 160, 104 (1.232); 112 (1.484).

45 Norris, The Ancient Cornish Drama, 1.352-3 (1.1628).

46 Spector, The N-Town Play, 1.314 (1.1). 